\title{
EMPLOYEE PROACTIVE PERSONALITY IN LEARNING CULTURE
}

\author{
Nury Ariani Wulansari ${ }^{\circledR}$, Ita Sulistyo Rini \\ Management Department, Faculty of Economics, Universitas Negeri Semarang \\ e-mail: nuryariani@mail.unnes.ac.id
}

\begin{abstract}
The paper attempts to investigate the influences of proactive personality and organizational learning culture on career satisfaction through Leader-Member Exchange quality as a mediating variable. Questionnaire was used as data collection method. The population of this study was Financial Cooperative employees based on health assessment in province level of Semarang City and Regency in 2015. Data was taken from 61 respondents using multi-stage sampling. From the result, it was found that (1) proactive personality influences career satisfaction, (2) organizational learning culture influences career satisfaction, (3) proactive personality influences Leader-Member Exchange quality, (4) organizational learning culture influences Leader-Member Exchange quality, (5) Leader-Member Exchange quality influences career satisfaction, (6) proactive personality influences career satisfaction through Leader-Member Exchange quality as mediator variable, and (7) organizational learning culture influences career satisfaction with Leader-Member Exchange quality as mediator variable. Proactive personality and organizational learning culture influence career satisfaction through Leader-Member Exchange as a mediating variable.
\end{abstract}

Keywords: proactive personality, organizational learning culture, career satisfaction, Leader Member Exchange quality

\begin{abstract}
Abstrak
Penelitian ini bertujuan untuk menguji pengaruh kepribadian proaktif dan budaya pembelajaran organisasi pada kepuasan karir dengan kualitas pertukaran pemimpin-anggota sebagai variabel pemediasi. Metode pengumpulan data menggunakan kuesioner. Populasi penelitian adalah karyawan KSP berdasarkan penilaian Kesehatan tingkat provinsi tahun 2015 di Kota dan Kabupaten Semarang. Sampel yang digunakan sebanyak 61 responden dengan menggunakan teknik pengambilan sampel multi-stage sampling. Hasil penelitian ini yaitu (1) kepribadian proaktif berpengaruh pada kepuasan karir, (2) budaya pembelajaran organisasi berpengaruh pada kepuasan karir, (3) kepribadian proaktif berpengaruh pada kualitas pertukaran pemimpinanggota, (4) budaya pembelajaran organisasi berpengaruh pada kualitas pertukaran pemimpinanggota, (5) kualitas pertukaran pemimpin-anggota berpengaruh pada kepuasan karir. Kepribadian proaktif dan budaya pembelajaran organisasi berpengaruh pada kepuasan karir melalui kualitas pertukaran pemimpin-anggota sebagai variabel pemediasi.
\end{abstract}

Kata kunci: kepribadian proaktif, budaya pembelajaran organisasi, kualitas pertukaran pemimpin-anggota, kepuasan karir. 


\section{INTRODUCTION}

Advances in an organization is determined by the quality of its Human Resources (HR). Human resources is one of the main driven of company's business activities, even its up and down process is set by HR (Ghoniyah \& Masurip, 2011). Organization presently faces difficulties in recruiting HR with appropriate skill for organization's needs (Barnett \& Bradley, 2007). In such a way, organization needs to support employees in order to keep their commitment for working in the organization. It is because that the support given by organization will direct employees to think that company pays enough attention to them (Erdogan \& Enders, 2007; Susmiati $\&$ Sudarma, 2015).

Example of supports given to employees are: supervisor support, co-worker support, training and career planning (Choi et al., 2012; Hillman \& McMillan, 2005; Huffman, Casper, \& Payne, 2013; Karatepe \& Uludag, 2008; Karatepe, 2012, 2013; Wickramasinghe \& Jayaweera, 2010; Yap et al., 2010). Amongst of all those supports, career has the biggest portion of attention put by employees in their working life in the organization (Putri \& Marton, 2015; S. E. Seibert \& Kraimer, 2001; Zacher, 2014).

According to Barnett and Bradley (2007), career satisfaction is the most important support comparing to other career supports. Moreover, career satisfaction is considered as a subject employed by employees to contrast between career has been achieved and their expectation on career achievement with an offer previously pledged by the organization (Sheel et al., 2012).

The study of Joo and Ready (2012) points that career satisfaction of employees is influenced by factors that is personal and contextual characteristics. One of personal characteristics affecting employee career satisfaction is personality (Loveland et.al., 2015).
Personality influencing on career satisfaction includes extraversion, neuroticism, conscientiousness, agreeableness, openness to experience, internal locus of control, and proactive personality (Subiaktono, 2013).

In meta-analysis done by $\mathrm{Ng}$ et al., (2005), among other personality types, the proactive personality type has a strong relationship with employee career satisfaction. This phenomenon happens because the more employees have a proactive personality, the more they will be satisfied in their career.

Employee having proactive personality will always find out information outside and inside of organization, with the result that the employee will be more satisfied on his career. It is in line with the study from Aryaningtyas and Suharti (2013) stated that, proactive personality of the employees had implied their willingness to be involved, initiative and contribution to organization in varied activities and situation.

Whereas one of contextual characteristics influencing employee career is culture. Culture is defined as embed values, customs and beliefs and it shapes attitude and behavior of an individual (Nahdluddin \& Maftukhah, 2015). Joo and Park (2010) suggested that the culture affecting employee career satisfaction is organizational learning culture.

This culture focuses on organization needs to adapt the environment change by learning from precedence, anticipate varied possibility and commit making innovation to build better future for organization (Lam et al., 2008).

The organization that implementing organizational learning culture will improve employees' ability, knowledge and skill. It makes easier for employee to reach his career he wants and it increases career satisfaction. In implementing organizational learning culture and stimulating employee proactive 
personality, the role of leader is compulsory (Joo \& Park, 2010; Camps \& Rodriguez, 2011; Islam et.al., 2013). Considering that leaders spark the goal, plan, organize, drive, and control resources of the company (Martono, 2013).

The behavior that influences employee career satisfaction is leader behavior in quality of Leader-Member ExchangeLMX (Joo \& Ready, 2012). The quality of Leader-Member Exchange (LMX) is deemed to be leader behavior focusing on personal relationship between leader and its subordinates (Volmer et al., 2012). The leader will create different quality of LeaderMember Exchange between two employees even though both have the same ability, skill and position. High quality Leader-Member Exchange between leader and his member enables to make upsurge career satisfaction perceived by employees because they will get benefits in the form of abundant information, more challenging task, and opportunity to participate in pivotal decision making.

It is consistent with Liden dan Maslyn (1998) finding, that is, there is a low (outgroup) and high (in-group) relationship concept of Leader-Member Exchange (LMX). Subordinates belonging to in-group are possible to obtain trust, respect and liked by the leader, while out-group subordinates only get limited authority based on contract of employment (Erdogan \& Enders, 2007). Employees hope that quality of LeaderMember Exchange in the organization is not interpreted as a gap between in-group and out-group since supports given by the leader for employee is very essential to increase career satisfaction, without discriminating certain employee among others.

This research took Financial Cooperative as the object of the study. Notwithstanding that Financial Cooperative falls under Microfinance institution, but Financial Cooperative has many branches and spread out in rural area which makes it is effective to enhance SMEs empowerment, especially for SMEs beyond banking service reach (Sarwoko, 2008). There is a significant rising of cooperative in Indonesia starting in 1967 until 2003 (www.bps.go.id). However, according to State Minister for Cooperatives Small and Medium Enterprises Indonesia, from 212 thousands of existing cooperatives, there are only 147 thousands that active as they have not been able to execute Annual Member Meeting (www. depkop.go.id). Similarly, it happens in cooperatives in Semarang City with 988 existing cooperatives, there are 121 inactive cooperatives $(12,25 \%)$ while in Semarang Regency from 626 existing cooperatives, 77 of them $(12,3 \%)$ are inactive.

Based on health assessment in province level of Financial Cooperative and Union Saving and Loan Unit in Semarang City and Regency in 2015, there are 15 Financial Cooperatives that had been assessed (www. dinkop-umkm.jatengprov.go.id). It indicates that those 15 Financial Cooperatives assessed by Cooperatives and MSMEs Agency of Central Java have been supported by employee who have good initiative in working and enable to make a change in Financial Cooperative. Therefore, those Financial Cooperatives can accomplish the job faster comparing to other Financial Cooperative. This type of behavior typically owned by employee having proactive personality. Besides, those Financial Cooperatives tells us that they had already implemented organizational learning culture in order to become faster in acquiring knowledge and technology in supporting employees' performance. Although the employees have had proactive personality and been supported by well-established organizational learning culture, but the employees have not been satisfied for their career, especially in terms of getting enough salary as they expected. 
Based on those aforementioned issues, the purpose of the research are (1) to investigate the influences of proactive personality and organizational learning culture on career satisfaction, (2) to investigate the influences of proactive personality and organizational learning culture on quality of Leader-Member Exchange, (3) to examine the influences of Leader-Member Exchange quality on career satisfaction and (4) to test the influences of proactive personality and organizational learning culture on career satisfaction with quality of Leader-Member Exchange as mediating variable in Financial Cooperative based on health assessment in province level of Semarang City and Regency in 2015.

\section{METHOD}

The population of this study was all employees of Financial Cooperative based on health assessment in province level of Semarang City and Regency in 2015, which are accounted as many as 15 Financial Cooperatives. Multi-stage sampling was prepared to be used as sampling method. It refers to sampling technique wherein the sampling is carried out in several stages and combining other sampling type using smaller sampling units at each stage (Ferdinand, 2014: 178). The result is 8 Financial Cooperative with 66 employees as the sample. Yet, only 61 questionnaires that could be proceeded because 3 of the questionnaires were not returned and 2 questionnaires were claimed inappropriate.

The independent variables are proactive personality and organizational learning culture, while as the mediator variable was quality of Leader-Member Exchange and last, career satisfaction became dependent variable. The proactive personality variable was measured by 10 items of questions belonging to Seibert et al. (1999). Examples of such items are "I am always wary of new ways that change my course of life", and "I have great power to build a change wherever I am." The organizational learning culture variables were measured by 13 questionnaire items of Marsick and Watkins (2003). Examples of the items used are "Within the organization, I am welcome to discuss mistakes in serving to learn from my co-workers' mistakes," and "In organizations, I identified the skills I need to complete the tasks in the future ".

Quality of Leader-Member Exchange variable was measured by 12 items of question from Liden dan Maslyn (1998). Examples of items used in the study are "I really like my personal supervisor", and "My supervisor is a kind person like a friend to me". The career satisfaction variable was measured by 5 question items belong to Greenhaus et al. (1990). Examples of items used are "I am satisfied with my career if I can achieve the career I want successfully", and "I am satisfied with my progress in achieving my overall career goals".

Methods of data collection used unstructured interview method and questionnaire. While the data was analyzed using partial analysis and path analysis with SPSS 21. In addition, the existing data also was tested in terms of the validity and reliability before being tested using partial analysis and path analysis.

\section{RESULT AND DISCUSSION}

Based on the results of descriptive test obtained from the respondents, it can be seen that from 61 respondents, $63.9 \%$ or 39 respondents are male and $36.1 \%$ or 22 respondents are female. So, it can be seen that the majority of employees working in Financial Cooperative are men.

While the number of respondents by age range can be seen in the following. Respondents aged 19-26 years are accounted for 16 people $(26.2 \%), 27-34$ years are 
accounted for 17 people (27.9\%), 35-42 years are accounted for 17 people $(27.9 \%)$, 43-50 years are 6 people (9.8\%), 51-58 years old are 2 people $(3.3 \%)$ and 59-66 years old are 3 people $(4.9 \%)$.

Based on the length of work, it can be seen that the respondents who work $1-5$ years as many as 41 people $(67.2 \%), 6-10$ years as many as 16 people $(26.2 \%)$ and as many as 4 people $(6,6 \%)$ worked more than 10 years. So, it can be inferred that the majority of employee had worked for 1-5 years.

In the validity test is known that all questions used in the questionnaire declared valid because it has $r$ count $>r$ table (0.252). So, there were no question items that were deleted in the questionnaire used. In addition, the reliability test of all instruments in the research variables is considered reliable because it has a value of Cronbach's alpha $>0.70$.

Through Classical Assumption Test the value of $\operatorname{sig}(2$-tailed) is $0.236>0.05$. So it can be concluded that the data in this study is normally distributed. In addition, the multicollinearity test shows that the proactive personality variable, organizational learning culture and Leader-Member Exchange quality have tolerance values $>0.10$ and have VIF value $<10$. So it can be interpreted that there is no multicolinierity. Then, based on heterocedastisity test, it is known value of sig from proactive personality variable, organizational learning culture and LeaderMember Exchange quality $>0,05$. This can be interpreted that the data in this study did not contain any heterocedastisity.

Based on Table 1 it is known that the proactive personality variable has a t count of 2.419 with a significance level of $0.019<0.05$ therefore $\mathbf{H 1}$ is supported, since proactive personality is proven to have a direct effect on employee career satisfaction. As a result, it is concluded that the proactive personality owned by Financial Cooperative employees can improve career satisfaction perceived during working at Financial Cooperative.

Based on table 1 it is known that the organizational culture learning variable has a t value of 3.976 with a significance level of $0.000<0.05$. So it can be concluded that, organizational learning culture has a direct influence on career satisfaction. Then, $\mathbf{H 2}$ is supported. This indicated that organizational learning culture variables applied by management of Financial Cooperative can improve career satisfaction perceived by the employees as long as the employees work at the Financial Cooperative.

Table 1. Proactive Personality and Organisational Learning Culture on Career Satisfaction

Coefficients $^{\mathrm{a}}$

\begin{tabular}{|c|c|c|c|c|c|c|}
\hline & \multirow{2}{*}{ Model } & \multicolumn{2}{|c|}{$\begin{array}{l}\text { Unstandardized } \\
\text { Coefficients }\end{array}$} & \multirow{2}{*}{$\begin{array}{c}\begin{array}{c}\text { Standardized } \\
\text { Coefficients }\end{array} \\
\text { Beta }\end{array}$} & \multirow{2}{*}{$\mathbf{t}$} & \multirow{2}{*}{ Sig. } \\
\hline & & B & Std. Error & & & \\
\hline \multirow{3}{*}{1} & (Constant) & $-1,320$ & 2,794 & & ,472 & 638 \\
\hline & Proact_Personality & , 174 & 072 & ,292 & ,419 & 019 \\
\hline & Org learn & ,256 &, 065 & ,479 & ,976 & 000 \\
\hline
\end{tabular}

a. Dependent Variable: Career_Satisfaction

Source: data processed, 2016 
From the data of table 2 it can be seen that the independent variable, proactive personality has an influence on the dependent variable, Leader-Member Exchange quality. This study used the significance of $5 \%$ (0.05). The proactive personality variable has a $t$ value of 3.24 with a significance level of $0.002<0.05$. So it can be concluded that proactive personality has a positive influence on the quality of Leader-Member Exchange, so $\mathbf{H 3}$ is supported. This indicated that the proactive personality possessed by Financial Cooperative employees was able to influence the high quality of Leader-Member Exchange perceived by the employee.

From the data of table 2 it can be seen that the organizational culture learning variable has a $t$ value of 3.44 with a significance level of $0.001<0.05$. This suggested that the organizational learning culture has a direct influence on the quality of Leader-Member Exchange, so that $\mathbf{H 4}$ is supported. Therefore, it can be concluded that the organizational learning culture has been applied by the Financial Cooperative management was able to influence the quality of Leader-Member Exchange that exist between the leader and employees.

From table 3 it can be seen that the quality of Leader-Member Exchange variable has a $t$ value of 5.052 with a significance level of $0,000<0.05$. Thus, H5 is supported, because the quality of LeaderMember Exchange is able to influence career satisfaction. So it can be concluded that the quality of well-established-Leader-Member Exchange quality between employees and their leaders was able to improve career satisfaction perceived by the employees.

Tabel 2. Proactive Personality and Organisational Learning Culture on Quality of LeaderMember Exchange

Coefficients $^{\text {a }}$

\begin{tabular}{|c|c|c|c|c|c|c|}
\hline & \multirow{2}{*}{ Model } & \multicolumn{2}{|c|}{$\begin{array}{l}\text { Unstandardized } \\
\text { Coefficients }\end{array}$} & \multirow{2}{*}{$\begin{array}{c}\begin{array}{c}\text { Standardized } \\
\text { Coefficients }\end{array} \\
\text { Beta }\end{array}$} & \multirow{2}{*}{$\mathbf{t}$} & \multirow{2}{*}{ Sig. } \\
\hline & & B & Std. Error & & & \\
\hline \multirow{3}{*}{1} & (Constant) &,- 912 & 5,779 & & , 158 & 875 \\
\hline & Proact_Personality & 484 & ,149 & ,384 & ,244 & 002 \\
\hline & Org_learn & ,459 & ,133 & ,407 & ,441 & 001 \\
\hline
\end{tabular}

a. Dependent Variable: LMX

Source: primary data processed, 2016

Table 3. Quality of Leader-Member Exchange on Career Satisfaction

\begin{tabular}{|c|c|c|c|c|c|c|}
\hline \multicolumn{7}{|c|}{ Coefficients $^{\mathbf{a}}$} \\
\hline & \multirow{2}{*}{ Model } & \multicolumn{2}{|c|}{$\begin{array}{l}\text { Unstandardized } \\
\text { Coefficients }\end{array}$} & \multirow{2}{*}{$\begin{array}{c}\begin{array}{c}\text { Standardized } \\
\text { Coefficients }\end{array} \\
\text { Beta }\end{array}$} & \multirow[t]{2}{*}{$\mathbf{t}$} & \multirow{2}{*}{ Sig } \\
\hline & & B & Std. Error & & & \\
\hline \multirow{2}{*}{1} & (Constant) & 8,175 & 2,226 & & 673 & 001 \\
\hline & LMX & ,261 &, 052 &, 550 &, 052 & 000 \\
\hline
\end{tabular}

a. Dependent Variabl: Career Satisfaction

Source: data processed, 2016 


\section{Path Analysis}

Table 4. Regression Analysis 1

Coefficients $^{\mathrm{a}}$

\begin{tabular}{|c|c|c|c|c|c|c|}
\hline & \multirow{2}{*}{ Model } & \multicolumn{2}{|c|}{$\begin{array}{c}\text { Unstandardized } \\
\text { Coefficients }\end{array}$} & \multirow{2}{*}{$\begin{array}{c}\begin{array}{c}\text { Standardized } \\
\text { Coefficients }\end{array} \\
\text { Beta }\end{array}$} & \multirow[t]{2}{*}{$\mathbf{t}$} & \multirow[t]{2}{*}{ Sig. } \\
\hline & & B & Std. Error & & & \\
\hline \multirow{3}{*}{1} & (Constant) &,- 912 & 5,779 & & , 158 & 875 \\
\hline & Proact_Personality & ,484 & 149 & ,384 & ,244 & 002 \\
\hline & Org_Learn & ,459 & ,133 & ,407 & ,441 & 001 \\
\hline
\end{tabular}

a. Dependent Variable: LMX

Source: data processed, 2016

Table 5. Regression Analysis 2

Coefficients $^{\mathrm{a}}$

\begin{tabular}{ccccccc}
\hline & & \multicolumn{2}{c}{$\begin{array}{c}\text { Unstandardized } \\
\text { Coefficients }\end{array}$} & $\begin{array}{c}\text { Standardized } \\
\text { Coefficients }\end{array}$ & t & Sig. \\
\cline { 2 - 5 } & B & Std. Error & Beta & &, 651 \\
\hline (Constant) & $-1,273$ & 2,803 & &,- 454 &, 062 \\
\hline Proact_Personality &, 150 &, 079 &, 250 & 1,905 &, 002 \\
\hline Org_Learn &, 233 &, 071 &, 435 & 3,282 &, 427 \\
\hline LMX &, 051 &, 064 &, 107 &, 801 & & \\
\hline
\end{tabular}

a. Dependent Variable: Career Satisfaction

Source: data processed, 2016

According to table 4, it is obtained the regression equation 1 as mentioned in the following:

Quality of Leader-Member Exchange $(\mathrm{Y} 1)=0,484$ (Proactive Personality) $+0,459$ (Organisational Learning Culture) + e 1

According to table 5, it is obtained regression equation 2 as follows:

Career Satisfation (Y2) = 0,150 (proactive personality) $+0,233$ (Organisational Learning Culture) $+0,051$ (Quality of Leader-Member Exchange) + e2

The value of $\mathrm{e} 1=\sqrt{ }(1-\mathrm{R}) 2$ means the coefficient of determination (R2) can be seen in the summary model table for the regression equation model 1 and the value of e $2=\sqrt{ }(1-$ R)2 means the coefficient of determination (R2) can be seen in summary model table for regression equation of model 2 . Therefore, the value of 1 can be counted by looking up table 6 and the value of e 2 in table 7.

$$
\begin{aligned}
& \text { Value of e } 1=\sqrt{ }(1-0,509) \\
& =\sqrt{ } 0,491 \\
& =0,701
\end{aligned}
$$

Residual (error) variable of proactive personality and organizational learning culture on the quality of Leader-Member Exchange is $70.1 \%$ which means that the dependent variable is influenced by other variables not tested in this study. 
Table 6. Model Summary of Regression Model 1

Model Summary

\begin{tabular}{ccccc}
\hline Model & R & R Square & Adjusted R Square & Std. Error of the Estimate \\
\hline 1 &, $713^{\mathrm{a}}$ &, 509 &, 492 & 4,893 \\
\hline
\end{tabular}

a.Predictor: Org_learn, Proact_Personality

Source: data processed, 2016

Table 7. Model Summary of Regression Model 2

Model Summary

\begin{tabular}{ccccc}
\hline Model & R & R Square & Adjusted R Square & Std. Error of the Estimate \\
\hline 1 &, $704^{\mathrm{a}}$ &, 496 &, 469 & 2,373 \\
\hline
\end{tabular}

a. Predictors: LMX, Proact_P, Org_Learn

Source: data processed, 2016

Table 8. Direct and Indirect Influence

\begin{tabular}{|c|c|c|c|c|c|}
\hline No & Variable & Influence & $\begin{array}{c}\text { Quality of } \\
\text { Leader-Member } \\
\text { Exchange } \\
\end{array}$ & $\begin{array}{c}\text { Career } \\
\text { Satisfaction }\end{array}$ & Total \\
\hline \multirow{3}{*}{1} & \multirow{3}{*}{$\begin{array}{l}\text { Proactive } \\
\text { Personality }\end{array}$} & Direct & --- & 0,150 & 0,150 \\
\hline & & Indirect & 0,484 & 0,051 & $0,484 \times 0,051=\mathbf{0 , 0 2 5}$ \\
\hline & & Total Influence & --- & --- & $0,150+0,025=0,175$ \\
\hline \multirow{3}{*}{2} & \multirow{3}{*}{$\begin{array}{l}\text { Organisational } \\
\text { Learning Culture }\end{array}$} & Direct & --- & 0,233 & 0,233 \\
\hline & & Indirect & 0,459 & 0,051 & $0,459 \times 0,051=0,023$ \\
\hline & & Total Influence & --- & --- & $0,233+0,023=0,256$ \\
\hline
\end{tabular}

Source: data processed, 2016

Value of e2 $=\sqrt{ }(1-0,496)$

$=\sqrt{ } 0,504$

$=0,71$

Residual (error) variable of proactive personality, organizational learning culture and quality of leader-member leadership on career satisfaction is $71 \%$ which means that the dependent variable is influenced by other variables not tested in this study.

Based on the above calculation, the gradual regression equation of this research is as follows:
Quality of Leader-Member Exchange $(\mathrm{Y} 1)=\beta$ (Proactive Personality) $+\beta$ (Organisational Learning Culture) + e 1

Means Quality of Leader-Member Exchange $=0,484+0,459+0,701$

Career Satisfaction $(\mathrm{Y} 2)=\beta$ (Proactive Personality) $+\beta$ (Learning Organizational Culture) $+\beta$ (Leader-Member Exchange) + e2

Career Satisfaction $=0,150+0,233+$ $0,051+0,71$. 


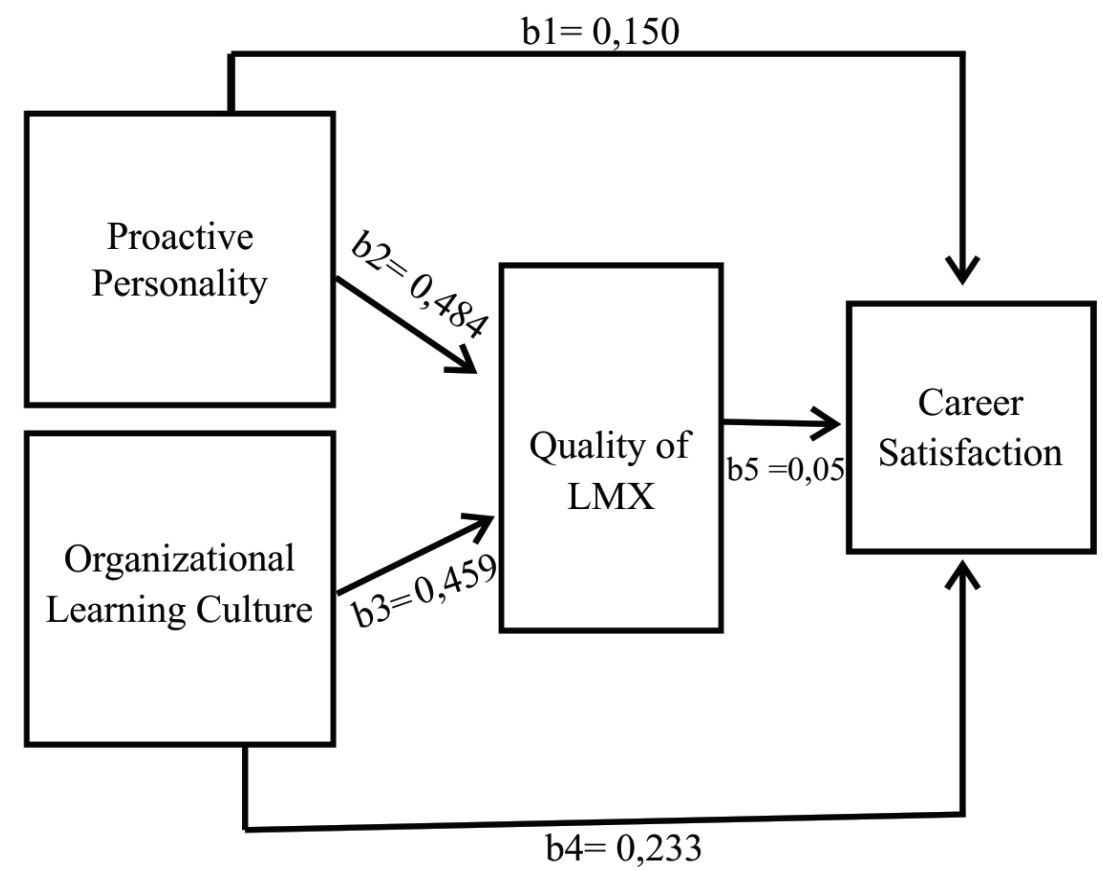

Figure 1.

Result of Path Analysis

Based on table 8, it can be deduced that the total influences of path coefficients is 0,175 while direct influences is 0,150 . Therefore, the total influences of path coefficient $>$ direct influences, that is $0,175>0,150$. Thus, proactive personality has positive impact on career satisfaction through quality of LeaderMember Exchange, "H6 is supported". It happens because the quality of LeaderMember Exchange successfully mediated the influences of proactive personality on career satisfaction.

Hypothesis one (H1) states that "proactive personality which influences positively on career satisfaction" is supported. It refers to the result of significance test ( $t$ test) claimed that significance level of proactive personality variable on career satisfaction variable, which is $0,019<0,05$, leading to $\mathbf{H 1}$ is supported. It means that proactive personality has positive impact on career satisfaction for Financial Cooperatives employees. Proactive personality owned by the employees will make them more active at work so they will perceive career satisfaction.
The higher of proactive personality, the higher career satisfaction will be perceived. This is also similar with the idea brought by Barnett and Bradley, 2007; Joo and Ready, 2012; Seibert et al., 1999; Yang and Chau, 2016 who declared that proactive personality has positive influence on career satisfaction.

Proactive personality is a type of personality possessed by employees who are active and having initiatives to create something new to improve themselves Seibert et al. (1999). Employees who possess proactive personality will not easily satisfy by only getting knowledge and information from the organization. Thus, proactive personality will make them to get career satisfaction faster comparing to other employees who does not have proactive personality (Barnett and Bradley,2007).

The result of descriptive analysis shows that indicator of proactive personality has index average value 77 or $29 \%$, which means that it was a high criteria. It showed that many Financial Cooperative employees 
agree with the statement in proactive personality indicator. It indicated that Financial Cooperative employees have already had proactive personality to support them to work. Those make them enable to perceive career satisfaction during doing their jobs. This personality has been reflected in employee's activeness in looking for new methods, delivering ideas, bringing it into reality, having initiatives to solve problems, even searching for long-term potential for their success.

Then, Hypothesis two (H2) stated that "organizational learning culture influence positively on employees' career satisfaction" was supported. This result was based on significance test ( $t$ test) showed that the significance of organizational learning culture variable on career satisfaction variable was $0,000<0,05$ which means that $\mathbf{H 2}$ is supported. It was inferred that organizational learning culture has significance and positive impact on career satisfaction. Therefore, the higher of organizational learning culture implementation in Financial Cooperative was, the higher career satisfaction perceived will be. It was in line with the study of Joo and Ready (2012) and Joo and Park (2010) found that organizational learning culture implementation will increase career satisfaction perceived by employees.

According to descriptive analysis result of organizational learning culture variable, it was known that average index value of organizational learning culture variable was $82,27 \%$ with high criteria. It showed that Financial Cooperatives employees thought that the organization has implemented organizational learning culture that support them to get new experience and knowledge. Organizational learning culture implemented also be able to improve employees' career satisfaction, especially in terms of advancement in supporting their career achievement.
Indicator of organizational learning culture that has the highest index value was "In Financial Cooperatives where I work, I respect other employees" with the index value was 88 or $12 \%$, included in high criteria. It indicated that Financial Cooperative employees have implemented culture of respect to enhance good relationship amongst employees. Therefore, Financial Cooperative employees can further improve learning in workplace through sharing with other employees. While the indicator with lowest index was "in Financial Cooperative where I work, employees openly discuss about mistakes had been made to learn together" with index value was 64 or $64 \%$, which was included as medium criteria. It indicated that the indicator of Financial Cooperative employees in discussing openly the mistakes in work was lower comparing to other indicators, but it was still in good category.

The result of interview with Chief of BMT EL-Labana (Monday, 27 June 2016) also showed that organizational learning culture has been implemented. BMT ELLabana is a Financial Cooperative which is established in 20 October 2009 and based on health assessment, it is included health enough category with the score of 77,75 and only have 3 employees. Chief of BMT ELLabana is always active to ask the employees to join varied education and training, both held by official agency or other party. As a result, employees of BMT EL-Labana have much knowledge to support their jobs. In fact, BMT EL-Labana has a good organization culture, before starting to work, which comes at $07.00 \mathrm{am}$, there was always a short discussion between employees and the chief about job at that day, do Duha prayer and a policy that all empoyees are required to read any book, newspaper, magazine, or other information out of the fieldwork at least for 10 minutes before BMT EL-Labana was officially opened at $08.00 \mathrm{am}$. 
Organizational learning culture implemented in BMT EL-Labana improved new skills, experiences, and knowledges to support the job. Thus, the jobs in BMT ELLabana can be accomplished in a good way, even though there are only 4 employees who carried it out. Moreover, BMT EL-Labana, which had been established 8 years ago, was able to be the top 10 of Financial Cooperatives having good score of health assessment at provincial level in 2015. It makes the leader interested to improve quality of LeaderMember Exchange in order to increase BMT performance to be even better.

Further, Hypothesis three (H3) in this study which states that "proactive personality positively affects the quality of Leader-Member Exchange" is supported. The support of $\mathrm{H} 3$ in this study is based on the results of the significance test ( $\mathrm{t}$ test) which shows that the proactive personality variable significance in the Leader-Member Exchange member quality variable is 0.002 $<0.05$, so that $\mathbf{H 3}$ is supported. This means that proactive personality has a positive and significant influence on the quality of LeaderMember Exchange. Proactive personality owned by an employee will make the employee more active in developing himself in the company.

Thus, the employees will often interact with their leader to seek important information or new knowledge about field of work. Employees who are able to make good relations with their leaders, then, will have a high quality of Leader-Member Exchange with the leaders. This is in accordance with the research of Li et al. (2010); Ng et al. (2005); Yang and Chau (2016); Zhang et al. (2012) which stated that, the higher the proactive personality of Financial Cooperative employees, the higher quality of Leader-Member Exchange perceived by the employee.

Based on the results of descriptive analysis on the proactive personality variable found that the average value of the proactive personality variable index of $77.29 \%$ and included in the high criteria. This indicates that KSP employees have a proactive personality that supports them in their work so that they influence the high quality of Leader-Member Exchange between Financial Cooperatives leaders and employees. The indicator "I always look for the best way to do things" is an indicator that has the highest index value of $84.98 \%$ with high criteria. This showed that Financial Cooperative employees are always looking for the best way to finish their work.

This makes Financial Cooperative employees often interact with their leaders to discuss on how best way to complete their work. So that the employee can build a good relationship with the leader and have high quality of Leader-Member Exchange. The indicator that has the lowest index value is "I am happy to fight for my ideas, even when I am against other employees" with an index score of $67.2 \%$ and moderate criteria. This indicated that Financial Cooperative employees in fighting for their ideas are lower in criteria than other indicators but are still within the limits of good values.

In Financial Cooperative, employees are required to be always active in creating new innovations and able to work effectively and efficiently. This happens because nowadays the competition between Financial Cooperative is getting tougher, there are competing by giving easy credit requirement, giving of cheap interest, using profit sharing system (BMT), longer payment period, and new product like: SIHAJI ( BMT AlHikmah), SISUQUR (Qurban Voluntary Saving of BMT Al-Hikmah). Thus, Financial Cooperative employees should always keep updating of current community needs, to create new products that are appropriate and readily accepted by their members.

In addition, the proactive personality of Financial Cooperative employees 
will improve the quality of memberleader exchanges established in Financial Cooperative, especially if one office only has 3 to 12 employees. This will further support the improvement of Leader-Member Exchange quality because the leader will be easier to reach subordinates and will have more close relationship when working with small number of subordinates compared with companies that have more than 30 employees in each office.

Further, Hypothesis four (H4) stated that "Organizational learning culture positively affects the quality of LeaderMember Exchange" is supported. The support of $\mathrm{H} 4$ is based on the result of significance test ( $t$ test) in this study which shows that the significance of organizational learning culture variables on quality of Leader-Member Exchange variable is $0.001<0.05$, so that $\mathrm{H} 4$ is supported. This means that organizational learning culture has a positive and significant influence on the quality of Leader-Member Exchange. The organizational learning culture applied by Financial Cooperative was very useful in improving the relationship between the leader and his subordinates. This happens because with the existence of organizational learning culture, employees are required to always be actively involved in education and training programs that have been planned by Financial Cooperative management. So that employees will often meet and interact with their leaders during the education and training programs. Higher interaction will make employees feel that the quality of Leader-Member Exchange with their leaders is higher. This is in accordance with the findings of Islam et al. (2013), that the organizational learning culture is able to improve the quality of Leader-Member Exchange in Financial Cooperative.

Organizational learning culture is a culture owned by an organization that has the capacity to conduct continuous learning ((Dewi \& Herachwati, 2010). Organizational learning culture owned by
Financial Cooperative include the resources provided by Financial Cooperative to support learning culture in the form of physical and non-physical facilities (opportunity to learn), employees are invited to be involved in solving Financial Cooperative problems, and the availability of a forum for discussion (informal meeting for employees). Thus, employees gain more knowledge and useful experience in completing their work.

The results of descriptive analysis indicated that the indicator of organizational learning culture has an average index value of $82.27 \%$ with high criteria. This indicates that employees agree when the Financial Cooperative has implemented an organizational learning culture. In addition, high scores also provide an overview that the learning culture that has been implemented by Financial Cooperative is very good and able to assist Financial Cooperative employees in completing their work. This happens because Financial Cooperative employees feel that their company has provided opportunities for learning, sharing with colleagues and leaders, feeling respected by other employees and can analyze the skills that will be needed in working.

Further, Hypothesis five (H5) stated that "Quality of Leader-Member Exchange positively influences employee career satisfaction" is supported. The support of this $\mathrm{H} 5$ is based on the results of t-test on this research indicating that the level of significance of variable quality of LeaderMember Exchange on career satisfaction is $0.000<0.05$, then $\mathbf{H 5}$ is supported. This means that the quality of Leader-Member Exchange has a positive and significant influence on career satisfaction. So the higher the quality of Leader-Member Exchange that exist between the leadership of Financial Cooperative and employees, the higher the career satisfaction perceived by Financial employees. This is consistent with Han (2010); Joo and Ready (2012); and Yang 
and Chau (2016), the high quality of LeaderMember Exchange between the leader and his subordinates will increase the career satisfaction perceived by employees.

High quality of Leader-Member Exchange will make Financial Cooperative employees easier to find information that will support the employee in achieving career satisfaction. This happens because leaders tend to pay more attention to employees who have a closer relationship (in-group) than with employees who have an out-group (Erdogan \& Enders, 2007).

Based on the result of descriptive analysis of Leader-Member Exchange quality variable, it is known that the average value of Leader-Member Exchange is $71,41 \%$ with high criteria. This indicates that Financial Cooperative employees has a high- memberleader exchange quality with their leaders. So it is possible for Financial Cooperative employees to gain new knowledge from their leader that is useful in improving career satisfaction.

Then, Hypothesis six (H6) stating that "Proactive personality influences employee career satisfaction with quality of LeaderMember Exchange as a mediating variable" is supported. The support of H6 is based on the result of path analysis which states that the total effect of path coefficient $>$ direct influence, that is $0.175>0.150$, then H6 is supported. This means proactive personality has a positive effect on career satisfaction through the quality of LeaderMember Exchange. This happens because the quality of Leader-Member Exchange successfully mediates the influence of proactive personality on career satisfaction. This study supports the results of Yang and Chau (2016), which declared that the quality of Leader-Member Exchange was able as mediator in the relationship of proactive personality influences and employee career satisfaction.
Financial Cooperative employees are indicated having a high proactive personality as seen from the average index value of $77.29 \%$ with high criteria. This makes Financial Cooperative employees always active in seeking knowledge and skills related to their work both in the office and outside. This is in accordance with the results of Vandenberghe and Ok (2013) research which claimed that, employees who focus on career achievement have a proactive personality, so the employees will be active to seek opportunities outside the organization and play an active role in the organization. Thus, Financial Cooperative employees will have more contribution for their company either by giving new ideas to their leader or having initiative to solve the problem even though it is beyond their responsibility as well as giving a good change for the progress of their company.

This led the Chief pays more attention to its employees such as inviting them to discuss potential problems in Financial Cooperative and provide an opportunity for employees to express their opinions on how to improve the performance of Financial Cooperative. Thus, employees feel that they have a high quality of Leader-Member Exchange with their leader that will allow employees to gain career opportunities in Financial Cooperative.

For example, employee A attends a training out of office. During the training, employee A gets information on how to do bookkeeping and record transactions using the latest accounting system. Employee A is able to apply his new knowledge to support his work so that his work will be completed and more accurate when completed using the accounting system. The leader, who has known that employee $\mathrm{A}$ is able to complete their work well and on time, tend to invite employee A to discuss the new accounting system. This makes employee A feels closer to their leader and has a high quality of 
Leader-Member Exchange with their leader. The leader who know good performance of employee A will propose employee $\mathrm{A}$ as a candidate to be promoted in the promotion of position. This will make employee A feels the satisfaction of his career.

Hypothesis seven (H7) stating that "organizational learning culture has an effect on employee career satisfaction with quality of Leader-Member Exchange as a mediator variable" is supported. The support of $\mathrm{H} 7$ is based on the result of path analysis which states that the total effect of path coefficient $>$ direct influence, that is $0.256>0.233$, it means that $\mathrm{H} 7$ is supported. In other words, organizational learning culture has a positive effect on career satisfaction through the quality of Leader-Member Exchange. This happens because the quality of LeaderMember Exchange successfully mediates the influence of organizational learning culture on career satisfaction.

Financial Cooperative employees feel that the implementation of organizational learning culture in Financial Cooperative has been good when it is reviewed from the average index value of $82.27 \%$ with high criteria. This makes it easier for employees to access information, add new knowledge, and gain new experiences and skills. In addition, one of dimension of organizational learning culture according to Marsick and Watkins (2003) is "to complement leadership strategy in learning" enabling employees to see their leaders role in advocating and supporting learning applied to Financial Cooperative. This makes the employees feel that their leaders are concerned with the progress of their employees in terms of new knowledge and skills. Thus, the application of an organizational learning culture will improve the quality of Leader-Member Exchange between the employees and their leaders (Islam et al, 2013)

High quality of Leader-Member Exchange will make Financial Cooperative employees more satisfied with their career (Joo \& Ready, 2012). For example Financial Cooperative applies a good learning culture by sending its employees to attend training from the official agency. The employee will gain new skills and knowledge from the training result. Thus, after the employee is in the office then, the Financial Cooperative leader will invite them to discuss about the new skills gained from the training. This will make employees feel that their leaders have more attention on improving skills owned by employees. Therefore, employees will establish good relationships with the leader. This makes the employee will find it easier to find important information about his work from the leader then the employee feels more satisfied about the career compared to if the employee is only supported with a good learning culture only.

\section{CONCLUSION AND SUGGESTION}

The conclusion of this study is that proactive personality has an effect on employee's career satisfaction, proactive personality influences the quality of LeaderMember Exchange, organizational learning culture influences quality of Leader-Member Exchange, organizational learning culture has an effect on career satisfaction, proactive personality influences career satisfaction through quality of Leader-Member Exchange as mediating variable and organizational learning affects career satisfaction through the quality of Leader-Member Exchange as mediating variables.

Suggestions for Financial Cooperative management are to improve the employees' proactive personality through a weekly discussion program, providing challenging tasks, giving employees the opportunity to convey ideas and thoughts that are useful for Financial Cooperative progress, creating employee gathering program which is a sharing event for employee about ups and 
downs working in Financial Cooperative including any bad experiences when completing their work and can also creating programs that often involve the leader and employees such as joint discussions, joint vacation events, and training that directly conducted by the Chief.

Some suggestions for Financial Cooperative employees are that employees should begin to realize the importance of proactive personality in working, supporting and participating in the company's efforts to implement organizational learning culture, and paying attention to their relationship with the leaders. While suggestions for subsequent research is that to add control variables, namely the last education and position because of the last education and positions of respondents are very influential on the magnitude of proactive personality and acceptance of respondents on organizational learning culture applied by the organization, test other personality types that also have an influence on career satisfaction and quality of Leader-Member Exchange.

\section{REFERENCES}

Aryaningtyas, A. T., \& Suharti, L. 2013. Keterlibatan Kerja sebagai Pemediasi Pengaruh Kepribadian Proaktif dan Persepsi Dukungan Organisasional terhadap Kepuasan Kerja. Jurnal Manajemen dan Kewirausahaan, 15(1), 23-32.

Barnett, B. R., \& Bradley, L. 2007. The Impact of Organisational Support For Career Development on Career Satisfaction. Career Development International, 12(7), 617-636.

BPS. Data Perkembangan Koperasi di Indonesia, Sumber: https://www.bps. go.id/linkTabelStatis/view/id/1321 yang diakses pada tanggal 25 Agustus 2016, pukul 11.00 WIB.
Camp, J., \& Rodriguez, H. 2011. Transformational Leadership, Learning, and Employability: Effects on Performance Among Faculty Members. Personnel Review, 40(4), 423- 442 .

Choi, S., Cheong, K., \& Freinberg, R. 2012. Moderating Effects of Supervisor Support, Monetary Rewards, and Career Paths on The Relationship Between Job Burnout and Turnover Intentions in The Context of Call Centers. Managing Service Quality, 22(5), $492-516$.

Dinkop dan UMKM. 2016. Hasil Penilaian Kesehatan Koperasi /USP TK. Provinsi TA. 2015 Tahun Buku 2014 (Posisi Triwulan I), Sumber: www.dinkop-umkm.jatengprov. go.id, yang diakses pada tanggal 11 Februari 2016.

2016. Rekapitulasi

Keragaan Koperasi Kabupaten/ Kota di Jawa Tengah, Sumber www.dinkop-umkm.jatengprov. go.id, yang diakses pada tanggal 11 Februari 2016.

Dewi, I. C., \& Herachwati, N. 2010. Analisis Dampak Kepemimpinan Transaksional dan Transformasional terhadap Pembelajaran Organisasi pada PT Bangun Satya Wacana Surabaya. Jurnal Manajemen Teori Dan Terapan, 3(3), 1-15.

Erdogan, B., \& Enders, J. 2007. Support From the Top: Supervisors Perceived Organizational Support as a Moderator of Leader - Member Exchange to Satisfaction and Performance Relationships. Journal of Applied Psychology, 92(2), 321330.

Ferdinand, A. 2014. Metode Penelitian Manajemen, Pedoman Penelitian untuk Penulisan Skripsi, Tesis 
dan Disertasi Ilmu Manajemen. Semarang: Badan Penerbit Universitas Diponegoro.

Ghoniyah, N., \& Masurip. 2011. Peningkatan Kinerja Karyawan melalui Kepemimpinan, Lingkungan Kerja dan Komitmen. Jurnal Dinamika Manajemen, 2(2), 118-129.

Greenhaus, J. H., Parasuraman, S., \& Wormley, W. M. 1990. Effects of Race on Organization Experiences , Job Performance Evaluations, and Career Outcomes. Academy Of Management Journal, 33(1), 64-86.

Han, G. (Helen). 2010. Trust and career satisfaction: the role of LMX. Career Development International, 15(5), 437-458.

Hillman, K., \& McMillan, J. 2005. Life satisfaction of Young Australians: Relationships between Further Education Training and Employment and General and Career Satisfaction. Australian Coucil for Educational Research.

Huffman, A. H., Casper, W. J., \& Payne, S. C. 2013. How Does Spouse Career Support Relate to Employee Turnover? Work Interfering With Family and Job Satisfaction as Mediators. Journal of Organizational Behavior.

Islam, T., Khan, S. U. ., Ahmad, U. N. U. B., \& Ahmed, I. 2013. Organizational Learning Culture and LeaderMember Exchange Quality: The Way to Enhance Organizational Commitment and Reduce Turnover Intentions. The Learning Organization, 20(4/5), 322-337.

Joo, B.-K. (Brian), \& Park, S. 2010. Career Satisfaction, Organizational Commitment, and Turnover Intention (The effects of Goal Orientation, Organizational Learning Culture and Developmental Feedback). Leadership \& Organization Development Journal, 31(6), 482500.

Joo, B.-K. (Brian), \& Ready, K. 2012. Career Satisfaction: The Influences of Proactive Personality, Performance Goal Orientation, Organizational Learning Culture, and LeaderMember Exchange Quality. Career Development International, 17(3), 276-295.

Karatepe, O. M. 2012. Perceived Organizational Support, Career Satisfaction, and A Study of Hotel Employees in Cameroon. International Journal of Contempory Hospitality Management, 24(5), 735-752.

performance Work Practices, Work Social Support and Their Effects on Job Embeddedness and Turnover Intentions. International Journal of Contempory Hospitality Management, 25(6), 903 - 921.

Karatepe, O. M., \& Uludag, O. 2008. Supervisor Support , WorkFamily Conflict, and Satisfaction Outcomes: An Empirical Study in the Hotel Industry. Journal of Human Resources in Hospitality \& Tourism, 7(2), 115-134.

Kementerian Koperasi dan UKM. Menkop: Reformasi Koperasi Harus Dilakukan di Seluruh Indonesia. www.depkop. go.id yang diunduh tanggal 13 September 2016.

Lam, M. ., Poon, G. K. ., \& Chin, K. 2008. An Organizational Learning Model for Vocational Education in the Context of TQM Culture. International Journal of Quality \& Reliability Management, 25(3), 238 - 255. 
Li, N., Liang, J., \& Crant, J. M. 2010. The Role of Proactive Personality in Job Satisfaction and Organizational Citizenship Behavior: A Relational Perspective. Journal of Applied Psychology, 95(2), 395-404.

Liden, R. C., \& Maslyn, J. M. 1998. Multidimensionafity of LeaderMember Exchange : An Empirical Assessment through Scale Development. Journal of Management, 24(1), 43-72.

Loveland, J., Lounsbury, J., Park, S.-H., \& Jackson, D. 2015. Are salespeople born or made? Biology, personality , and the career satisfaction of salespeople. Journal of Business \& Industrial Marketing, 30(2), 233240.

Marsick, V. J., \& Watkins, K. E. 2003. Advances in Developing Human Resources. Advances in Developing Human Resources, 5(2), 132-151.

Martono, S. 2013. Strategi Peningkatan Kinerja Proram Studi melalui Optimalisasi Peran Pimpinan. Jurnal Dinamika Manajemen, 4(1), 30-45.

Nahdluddin, M., \& Maftukhah, I. 2015. Pengaruh Motivasi Kerja, Budaya Organisasi, dan Kualitas Kehidupan Kerja terhadap Kinerja Karyawan. Management Analysis Journal, 4(3), 219-228.

Ng, T. W. H., Eby, L. T., Sorensen, K. L., \& Feldman, D. C. 2005. Predictors of Objective and Subjective Career Success: A Meta-Analysis. Personnel Psychology, 58, 367-408.

Putri, G. R., \& Marton, S. 2015. Pengaruh Karakteristik Pekerjaan, Pengembangan Karir, dan Stres Kerja terhadap Komitmen Organisasi. Manajement Analysis Journal, 4(4), 301-309.
Sarwoko, E. 2008. Analisis Peranan Koperasi Simpan Pinjam/Unit Simpan Pinjam dalam Upaya Pengembangan UMKM. Modernisasi, 5(3), 172188.

Seibert, S. E., Crant, J. M., \& Kraimer, M. L. 1999. Proactive personality and Career Success. The Journal of Applied Psychology. http://doi. org/10.1037/0021-9010.84.3.416

Seibert, S. E., \& Kraimer, M. L. 2001. The Five-Factor Model of Personality and Career Success. Journal of Vocational Behavior, 58, 1-21.

Sheel, S., Sidhawani, D. B. ., Goel, S., \& Pathak, S. 2012. Quality Of Work Life , Employee Performance And Career Growth Opportunities : A Literature Review. International Journal of Multidisciplinary Research, 2(2), 291-300.

Subiaktono. 2013. Pengaruh Personality Traits terhadap Perencanaan Keuangan Keluarga. Jurnal Dinamika Manajemen, 4(2), 150-163.

Susmiati, \& Sudarma, K. 2015. Pengaruh Budaya dan Dukungan Organisasi Persepsian terhadap Kinerja Karyawan dengan Komitmen Organisasi sebagai Variabel Intervening. Manajement Analysis Journal, 4(1), 79-87.

Vandenberghe, C., \& Ok, A. B. 2013. Career Commitment, Proactive Personality , and Work Outcomes: A CrossLagged Study. Career Development International, 18(7), 652-672.

Volmer, J., Spurk, D., \& Niessen, C. 2012. Leader - Member Exchange (LMX), job autonomy, and Creative Work Involvement. The Leadership Quarterly, 23 (3), 456-465.

Wickramasinghe, V., \& Jayaweera, M. 2010. Impact of Career Plateau 
and Supervisory Support on Career Satisfaction: A Study in Offshore Outsourced IT Firms in Sri Lanka. Career Development International, 15 (6), 544-561.

Yang, F., \& Chau, R. 2016. Proactive Personality and Career Success. Journal of Managerial Psychology, 31 (2), -.

Yap, M., Robert, M. H., Hannan, C.-A., \& Cukier, W. 2010. The Relationship Between Diversity Training, Organizational Commitment, and career Satisfaction. Journal of
European Industrial Training, 31 (6), 519-538.

Zacher, H. 2014. Career Adaptability Predicts Subjective Career Success Above and Beyond Personality Traits and Core Self-Evaluations. Journal of Vocational Behavior, 84 (1), 21-30.

Zhang, Z., Wang, M. O., \& Shi, J. 2012. Leader-Follower Congruence in Proactive Personality and Work Outcomes: the Mediating Role of Leader-Member Exchange, 55(1), 111-130. 